\title{
Food-resource partitioning among fish species from a first-order stream in northwestern Paraná, Brazil
}

\author{
Jislaine Cristina da Silva ${ }^{1}$, Rosilene Luciana Delariva ${ }^{2}$ and Karine Orlandi Bonato ${ }^{3}$
}

This study addressed the feeding ecology of fish fauna from a first-order stream located in a rural area. The purposes were to evaluate the influence of interspecific, seasonal and spatial factors on the diet, examine the dietary overlap, and determine the predominant food sources. Sampling was conducted in December 2007, September 2008, and March 2009, in three 50-m stretches of Itiz stream (upstream, intermediate, and downstream), through electrofishing. A total of 1,102 stomach contents were analyzed from 14 species, by the volumetric method. In general, allochthonous resources were predominant in the diets. Astyanax aff. fasciatus, Astyanax aff. paranae, Astyanax bockmanni, and Bryconamericus aff. iheringi consumed a higher proportion of plant remains, and Bryconamericus stramineus consumed predominantly Hymenoptera. The diets of Cetopsorhamdia iheringi, Characidium aff. zebra, Imparfinis schubarti, and Trichomycterus sp. consisted of aquatic insects, especially immature forms of Trichoptera, Ephemeroptera, Plecoptera, and Diptera. Hypostomus ancistroides, Hisonotus sp., Poecilia reticulata, and Rineloricaria aff. pentamaculata exploited mainly detritus, while Rhamdia quelen used a variety of items, predominantly terrestrial insects. Detrended Correspondence Analysis (DCA) showed a clear distinction among the species, with different morphology and feeding tactics. The Multi-Response Permutation Procedure (MRPP) supported this differentiation, and also indicated significant spatial and temporal variations in the dietary composition; the Indicator Value Method (IndVal) indicated the main items that contributed to these differences. The diet overlap among species was low $(<0.4)$ to around $78 \%$ of pairs, and the mean value did not vary significantly among the sites or between hydrological periods within each site. According to the null model of Pianka's index, the values for dietary overlap were significantly higher than expected at random, showing evidence of resource sharing. This was related to the availability of allochthonous resources, highlighting the importance of riparian vegetation as a source of these resources for maintaining the fish fauna of the stream.

Este estudo abordou a ecologia alimentar da ictiofauna de um riacho de primeira ordem situado em área rural. Os objetivos foram verificar a influência dos fatores interespecíficos, sazonais e espaciais sobre a dieta, avaliar a sobreposição alimentar, além de determinar os recursos alimentares predominantes. As amostragens foram realizadas em dezembro/2007, setembro/ 2008 e março/2009, em três pontos do riacho Itiz (montante, intermediário e foz) com extensões de $50 \mathrm{~m}$, através de pesca elétrica. Foram analisados 1102 conteúdos estomacais referentes a 14 espécies de acordo com o método volumétrico. De forma geral observou-se que a maior contribuição na dieta das espécies foi de recursos alóctones. Astyanax aff. fasciatus, Astyanax aff. paranae, Astyanax bockmanni, Bryconamericus aff. iheringi, consumiram maior proporção de vegetal e Bryconamericus stramineus predominantemente Hymenoptera. Cetopsorhamdia iheringi, Characidium aff. zebra, Imparfinis schubarti $\mathrm{e}$ Trichomycterus sp. tiveram sua dieta baseada em insetos aquáticos, especialmente formas imaturas de Trichoptera, Ephemeroptera, Plecoptera e Diptera. Hypostomus ancistroides, Hisonotus sp., Poecilia reticulata e Rineloricaria aff. pentamaculata exploraram principalmente detrito, enquanto Rhamdia quelen usou uma variedade de itens, com predomínio de insetos terrestres. A análise de Correspondência com Remoção do Efeito do Arco (DCA) demonstrou uma segregação evidente entre as espécies com morfologia e táticas alimentares distintas. O Procedimento Permutacional de Multiresposta (MRPP) além de corroborar essa diferenciação, também mostrou variações espaciais e temporais significativas na composição da dieta das espécies, e o Método de Valor Indicador (IndVal) apontou os principais itens que contribuíram para essas diferenças. A sobreposição alimentar entre as espécies foi baixa $(<0.4)$ para cerca de $78 \%$ dos pares e a média não variou significativamente entre os locais, assim como entre os períodos hidrológicos dentro de cada ponto. De acordo com o modelo

${ }^{1}$ Universidade Estadual do Oeste do Paraná, Programa de Pós-Graduação em Conservação e Manejo de Recursos Naturais. Rua Universitária 2069, Caixa Postal 711,85819-110 Cascavel, PR, Brazil. jislainebio@yahoo.com.br

${ }^{2}$ Universidade Estadual do Oeste do Paraná, Centro de Ciências Biológicas e da Saúde. Rua Universitária 2069, Caixa Postal 711, 85819110 Cascavel, PR, Brazil.rldelariva@hotmail.com

${ }^{3}$ Universidade Federal do Rio Grande do Sul, Programa de Pós-Graduação em Biologia Animal, Departamento de Zoologia. Av. Bento Gonçalves 9500, Prédio 43435, 91501-970 Porto Alegre, RS, Brazil. kakabio2005@yahoo.com.br 
nulo do índice de Pianka, os valores de sobreposição alimentar foram significativamente maiores do que o esperado ao acaso, apresentando evidência de partição de recursos. Isto se deve à disponibilidade de itens alóctones, evidenciando a importância da mata ciliar como fonte desses recursos para a manutenção da ictiofauna do riacho estudado.

Key words: Allochthonous resources, Diet, Fish fauna, Trophic segregation, Riparian vegetation.

\section{Introduction}

Studies on trophic ecology have revealed a dietary pattern for fish from Neotropical streams, where the diet is mainly based on allochthonous food resources (Casatti, 2002; Mazzoni et al., 2010a; Tófoli et al., 2010), with the maximum use of environmental resources (Brandão-Gonçalves et al., 2010; Rezende et al., 2011) and high trophic plasticity of the species (Lowe-McConnell, 1999; Abelha et al., 2001).

However, some mechanisms are still little understood by ecologists, such as resource partitioning and other factors that allow the species to coexist (Esteves \& Galetti, 1994; Gerking, 1994; Higgins \& Strauss, 2008). Therefore, dietary analysis may reveal important information about trophic dynamics and resource partitioning among fish species (Ross, 1986), especially with regard to environments that are subject to sudden changes, such as streams (Johnson \& Arunachalam, 2012).

The high trophic plasticity allows Neotropical fishes to adjust their feeding habits to fluctuations in food supply (Balassa et al., 2004). Both stochastic processes and the abundance of some foods may reduce intraspecific competition, facilitating the species' coexistence (Dias \& Fialho, 2011; Uieda \& Pinto, 2011). Other factors such as trophic morphology, use of different microhabitats, periods of activity, and tactics of capture can minimize overlap effects (Casatti, 2002; Brazil-Sousa et al., 2009; Cetra et al., 2011).

The trophic opportunism observed for Neotropical fish fauna is influenced by the great variety of foods and is also related to the considerable temporal and spatial variations in the streams (Power, 1983; Winemiller \& Winemiller, 2003; Esteves et al., 2008; Johnson \& Arunachalam, 2012). In these environments, seasonal variations in the diet of fish species are common, with a wider niche breadth during the rainy season; in the dry season, these species become more specialized in a subset of resources (Winemiller et al., 2008). Nevertheless, in some environments these differences may not exist because the food resources remain available throughout the year in sufficient amounts (Mazzoni et al., 2010a; Schneider et al., 2011).

Streams are highly variable environments (Higgins, 2009; Winemiller et al., 2008) and have great habitat heterogeneity, with rocky rapids, pools, and small backwaters, which influence the composition of the fish fauna (Esteves \& Aranha, 1999; Casatti et al., 2001; Casatti, 2002). These different characteristics along the stream, as well as the characteristics of the surroundings, also determine the availability of food resources in the ecosystem.

Tropical landscapes have undergone widespread and continuing deforestation (Achard et al., 2002; Lambin et al.,
2003), and are increasingly dominated by agriculture, a very common situation in northwestern Paraná State and the vicinity of the Ivaí River basin (Parolin et al., 2010). The small rivers in this basin are quite heterogeneous, with distinct geomorphological and hydrological features (Leli et al., 2010; Parolin et al., 2010; Araújo et al., 2011). This heterogeneity contributes to the presence of a peculiar and endemic fish fauna (Maier et al., 2008), as in the Itiz stream, a rural stream that supports a high abundance of native species (Araújo et al., 2011).

Clearing of forests surrounding tropical streams is a critical threat to biodiversity, and may negatively impact the aquatic biota through habitat degradation and changes in the available food for the organisms (Lorion \& Kennedy, 2009; Casatti, 2010). These changes influence the contribution of allochthonous resources from the terrestrial environment, which are essential for stream fish (Alvim \& Peret, 2004; Rezende \& Mazzoni, 2005; Winemiller et al., 2008; Tófoli et al., 2010). Riparian vegetation is of paramount importance in sustaining these ecosystems, by influencing the transfer of solar energy to the environment, intercepting sediments that enter streams, and providing food and shelter for the fish fauna (Pusey \& Arthington, 2003; Abilhoa et al., 2008).

In the present study, the fish fauna from a first-order stream with different proportions of riparian vegetation was used to evaluate the hypothesis that the heterogeneity of the channel and surrounding environment will favor partitioning of food resources. The purposes of this study were to: (i) describe the feeding habits of the species; (ii) test the influence of interspecific, seasonal and spatial factors on the diet; (iii) examine the level of diet overlap among fish species; and (iv) determine the sources of the predominant resources in the species' diet.

\section{Material and Methods}

Study area. The study was performed in Itiz stream, a firstorder stream (Strahler, 1957), located in Marialva Municipality, State of Paraná. This stream flows into other tributaries of Pinguim stream, which flows into the Ivaí River. The Ivaí River watershed has an area of $36,899 \mathrm{~km}^{2}$ and a total course of 675 $\mathrm{km}$, and is the second-largest basin and the second-longest river in Paraná (Suderhsa, 2009).

Itiz stream is situated in a rural area (Fig. 1) where the main economic activity is the cultivation of soybeans, wheat, corn, sugarcane and grapes (Ipardes, 2007). The main physical characteristics and geographical coordinates of the three sampling stations along the stream are listed in Table 1 and Fig. 1. 


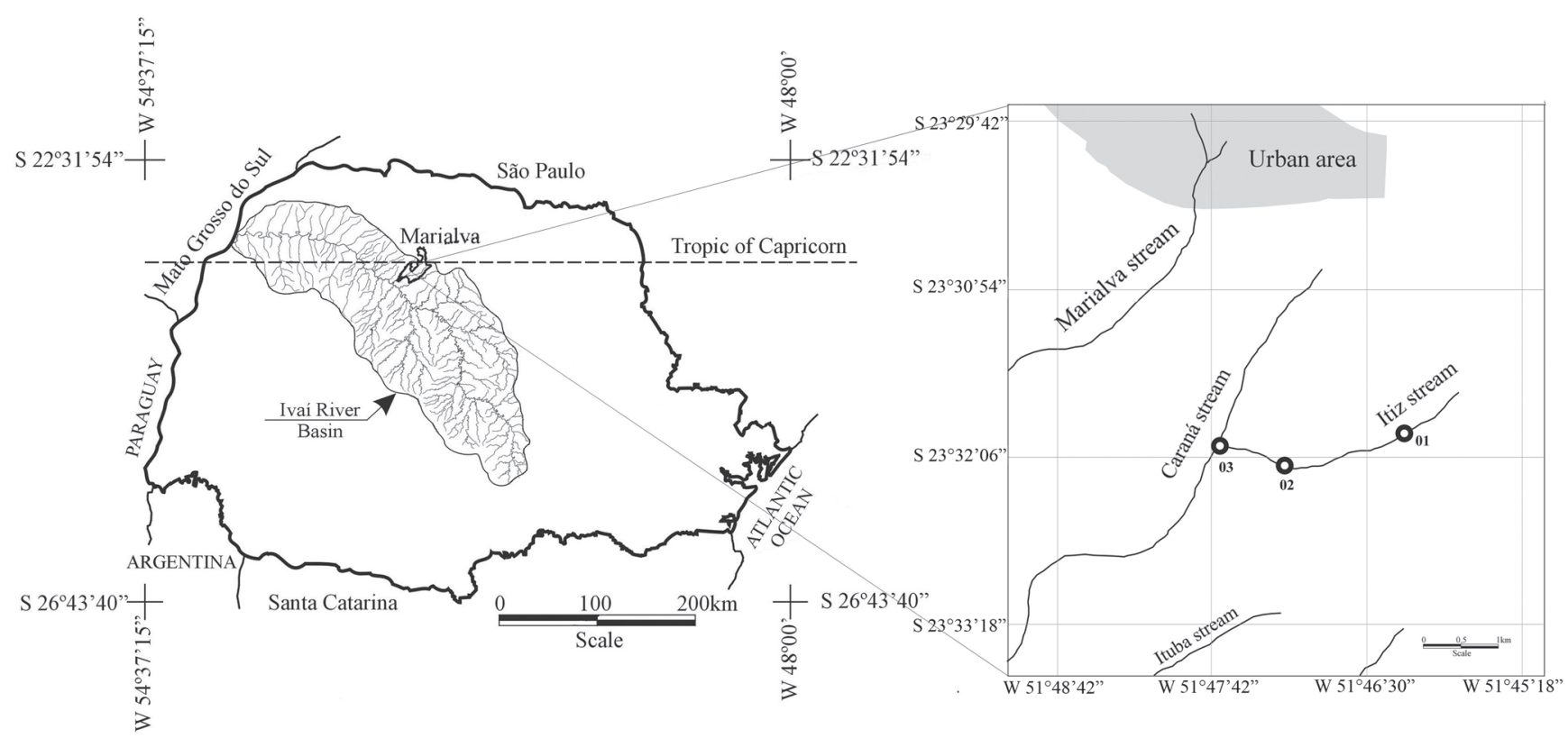

Fig. 1. Location of Itiz stream in the Ivaí River basin, state of Paraná, Brazil, indicating sampling sites (1,2 and 3).

Fish collections. Fish were collected at three sampling stations located in the upstream, intermediate and downstream regions, with an approximate distance of $1.2 \mathrm{~km}$ between each station, during December 2007, September 2008 and March 2009 (Fig. 1). For the sampling, we used electrofishing with three passes of $30 \mathrm{~min}$ each, in stretches of $50 \mathrm{~m}$ per sampling station. The electrofishing equipment was powered by a portable generator (Honda, $2.5 \mathrm{~kW}, 220 \mathrm{~V}$, 3--4 A) connected to a DC transformer, with two electrified net rings (anode and cathode). Output voltage varied from 400 to $600 \mathrm{~V}$. For the sampling we installed blocking nets (mesh size $0.5 \mathrm{~mm}$ ) at the ends of each stretch to prevent any fish from escaping. After sampling, fish were anesthetized with benzocaine $(250 \mathrm{mg} / \mathrm{L})$ and fixed in $10 \%$ formalin. Fish were collected under license from the Instituto Brasileiro do Meio Ambiente e dos Recursos Naturais Renováveis (IBAMA; Process number 11253-1/2007).

Specimens were identified according to Graça \& Pavanelli (2007), and then preserved in 70\% ethanol. Each specimen captured was weighed on an analytical balance (standard and total lengths, in $\mathrm{cm}$ ), and then eviscerated. Voucher specimens were deposited in the fish collection of Nupélia

Table 1. Physical characteristics of the sampling sites in Itiz stream, Ivaí River basin, Marialva Municipality, Paraná State, Brazil.

\begin{tabular}{|c|c|c|c|c|c|c|c|}
\hline Sites & Coordinates & $\begin{array}{l}\text { Width } \\
(\mathrm{m})\end{array}$ & $\begin{array}{l}\text { Depth } \\
(\mathrm{m})\end{array}$ & $\begin{array}{c}\text { Predominant } \\
\text { substrate }\end{array}$ & $\begin{array}{l}\text { Riparian } \\
\text { vegetation }\end{array}$ & $\begin{array}{c}\text { Channel } \\
\text { physiography }\end{array}$ & Observations \\
\hline 1 & $\begin{array}{l}23^{\circ} 31^{\prime} 49.9 ” \mathrm{~S} \\
51^{\circ} 46^{\prime} 26.9^{\prime \prime} \mathrm{W}\end{array}$ & $1.5-3.0$ & $0.10-0.50$ & $\begin{array}{l}\text { Gravel, pebble, } \\
\text { sand, silt and } \\
\text { litter }\end{array}$ & $\begin{array}{l}\text { Range of trees and } \\
\text { shrubs at or higher } \\
\text { than } 30 \mathrm{~m} \text { on the } \\
\text { banks }\end{array}$ & $\begin{array}{l}\text { Rapids with mean } \\
\text { depth of } 0.20 \mathrm{~m} \text {, and } \\
\text { pools up to } 0.60 \mathrm{~m} \\
\text { deep }\end{array}$ & $\begin{array}{l}\text { There is a disabled weir next } \\
\text { to the sampling station, and } \\
\text { water is pumped from the } \\
\text { middle of the sampling } \\
\text { stretch to irrigate nearby } \\
\text { fields. Surrounding } \\
\text { vegetation provides about } \\
80 \% \text { shade }\end{array}$ \\
\hline 2 & $\begin{array}{l}23^{\circ} 32^{\prime} 11.2^{\prime \prime} \mathrm{S} \\
51^{\circ} 46^{\prime} 59^{\prime \prime} \mathrm{W}\end{array}$ & $1.5-4.5$ & $0.10-0.20$ & $\begin{array}{l}\text { Rock, gravel, } \\
\text { pebble; some } \\
\text { backwaters with } \\
\text { sand and mud }\end{array}$ & $\begin{array}{l}\text { Range of trees and } \\
\text { shrubs at or higher } \\
\text { than } 30 \mathrm{~m} \text { on the } \\
\text { banks, with little } \\
\text { aquatic vegetation }\end{array}$ & $\begin{array}{l}\text { Pools } 5 \mathrm{~m} \text { wide and up } \\
\text { to } 1.20 \mathrm{~m} \text { deep; } \\
\text { stretches with rapids } \\
0.10 \text { to } 0.20 \mathrm{~m} \text { deep; } \\
\text { few backwater areas }\end{array}$ & $\begin{array}{l}1.5-\mathrm{m} \text { high waterfall } \\
\text { upstream. Stretch with better- } \\
\text { conserved riparian } \\
\text { vegetation, with } 90 \% \text { shade }\end{array}$ \\
\hline 3 & $\begin{array}{l}23^{\circ} 32^{\prime} 02.6^{\prime \prime} \mathrm{S} \\
51^{\circ} 46^{\prime} 26.3^{\prime \prime} \mathrm{W}\end{array}$ & $2.0-4.0$ & $0.30-0.50$ & $\begin{array}{l}\text { Rock, pebble, } \\
\text { litter and sand }\end{array}$ & $\begin{array}{l}\text { Range of trees lower } \\
\text { than } 10 \mathrm{~m} \text { and } \\
\text { invasive grasses }\end{array}$ & $\begin{array}{l}\text { Stretches composed of } \\
\text { rapids and sand }\end{array}$ & $\begin{array}{l}1.5-\mathrm{m} \text { high waterfall } \\
\text { downstream; stretch with the } \\
\text { lowest proportion of riparian } \\
\text { vegetation, and walking trails } \\
\text { along the banks. About } 50 \% \\
\text { shade }\end{array}$ \\
\hline
\end{tabular}


(Núcleo de Pesquisas em Limnologia, Ictiologia e Aquicultura), of the State University of Maringá, Brazil (Table 2).

Diet analysis. Gastric contents of 14 species based on all stomachs with food (fullness equal to or greater than 20\%) were identified under optical and stereoscopic microscopes to the lowest taxonomic level possible. For species with an undifferentiated stomach, the contents of the anterior third of the digestive tube were examined. For the analysis of stomach contents, we used only species for which we had a total of five or more samples. Food items were identified using the identification keys of Bicudo \& Bicudo (1970) for algae and of Mugnai et al. (2010) for invertebrates, and quantified according to the volumetric method; i.e., the total volume of a food item taken by the fish population is given as a percentage of the total volume of all stomach contents (Hyslop, 1980), using graduated test tubes and a glass counting plate (Hellawell \& Abel, 1971).

Statistical analysis. A multivariate ordination technique (Detrended Correspondence Analysis, DCA; Hill \& Gauch, 1980) was used to ordinate and summarize data for the species $\operatorname{diet}$ (Sheldon \& Meffe, 1993). The input matrix for the DCA contained the value for the volume of each food item. Because some food items showed high values, we conducted a squareroot transformation to minimize their effect on the ordination. In addition, we opted to run the DCA algorithm giving less weight to rare food items, also to remove their effect on the ordination. The first two DCA axes were retained for interpretation, because they showed eigenvalues greater than 0.20 (as recommended by Matthews, 1998).

The Multi-Response Permutation Procedure (MRPP) (McCune \& Grace, 2002) was used to test the significance of differences in dietary composition among the 14 species, sites $(1,2,3)$ and hydrological period (rainy - December 2007 and March 2009; and dry - September 2008), which were established through rainfall data obtained from the Weather Station of the State University of Maringá. MRPP is a non-parametric procedure for testing the null hypothesis of no difference between two or more groups of entities defined a priori. MRPP provides a test statistic ( $\mathrm{T}$ ) that describes the separation between the groups (the more negative the $\mathrm{T}$ value, the stronger the separation); a measure of "effect size" (A) is presented as a measure of the degree of within-group homogeneity, compared to random expectation where $(A \max =1$ is when all items are identical within groups), and a $p$-value is useful for evaluating the likelihood that an observed difference is due to chance (the significance level used was $<0.05$ ) (McCune \& Grace, 2002). As the input distance matrix, we selected the Sørensen (Bray-Curtis) distance, with $\mathrm{n} /$ $\operatorname{sum}(\mathrm{n})$ as the weighting factor.

The Indicator Value Method (IndVal), based on relative abundance and relative frequency, was used to detect how strongly each food item differed among sites and hydrological periods, according to the formula (Dufrêne \& Legendre, 1997):

$$
\operatorname{IndVal}_{\mathrm{ij}}=\mathrm{A}_{\mathrm{ij}} \times \mathrm{B}_{\mathrm{ij}} \mathrm{x} 100
$$

where: $\operatorname{IndVal}_{\mathrm{ij}}$ is the indicator value for species $\mathrm{i}$ in group $\mathrm{j}$, $A_{i j}$ is the relative abundance of species $i$ in group $j$ and $B_{i j}$ is the relative frequency of species $i$ in group $j$.

The indicator value of a food item varies from 0 to 100 , and attains its maximum value when all items occur at all sites and hydrological periods within a single group. We tested the significance of the indicator value for each item with a Monte Carlo randomization procedure with 10,000 permutations (the level of significance was $<0.05$ ). All statistical analyses and ordinations were performed in PCORD version 5.0 (McCune \& Mefford, 1999).

Feeding overlap. For this analysis we used the 32 items found in the analysis of food types. Feeding overlap was measured for each site in both hydrological periods, using the Pianka index (1973), according to the formula:

$$
\mathrm{O}_{\mathrm{jk}}=\sum \mathrm{P}_{\mathrm{ij}} \mathrm{P}_{\mathrm{ik}} / \sqrt{ }\left(\sum \mathrm{P}_{\mathrm{ij}} \sum \mathrm{P}_{\mathrm{ik}}\right)
$$

where: $\mathrm{O}_{j k}=$ Pianka's measure of niche overlap index between species $j$ and $k ; \mathrm{p}_{i j}=$ proportion of resource $i$ of the total resources used by species $j ; \mathrm{p}_{i k}=$ proportion of resource $i$ of the total resources used by species $k$; and $\mathrm{n}=$ total number of resource states.

Overlap values were set at the following levels: high $(>0.6)$, intermediate (0.4-0.6) or low ( $<0.4)$ (Grossman, 1986; Novakowski et al., 2008; Dias \& Fialho, 2011). This index assumes that prey are equally available to all predators (Reinthal, 1990). To test differences in niche overlap for each site and hydrological period within each site, we used the non-parametric Kruskal-Wallis test in the software Statistica 7.1 (StatSoft, 2005).

We used a null model to evaluate the significance of Pianka's index (Juliano \& Lawton, 1990; Winemiller \& Pianka, 1990; Tokeshi, 1999). In this null model, the observed percentage of food-category values were randomized 10,000 times within each site in both hydrological periods, and for each randomization the Pianka's index was calculated. The $p$ value for the observed index was estimated as the proportion of the randomized index that was greater than the observed value. The null model analysis and feeding overlap were computed using EcoSim 7.0 (Gotelli \& Entsminger, 2001).

Food resources. The items identified were grouped for graphical observation of the main food resources consumed by the species at the three sampling sites and in each hydrological period. The groupings were: aquatic invertebrates (Testate Amoebae, Gastropoda, Acarina, Amphipoda, Decapoda, Cladocera, Conchostraca, Copepoda, Ostracoda, Ephemeroptera, Odonata nymph, Plecoptera, immature Coleoptera, Trichoptera, immature Diptera, immature Lepidoptera, and aquatic insect remains), terrestrial invertebrates (Oligochaeta, Diplopoda, Araneae, Hemiptera, Hymenoptera, Coleoptera, adult Diptera, Orthoptera, and terrestrial insect remains), detritus, terrestrial plants (plant remains and seeds), algae, and fish (fish and scales). 


\section{Results}

Diet composition. The composition of the diet of 1,102 individuals belonging to 14 species was analyzed (Table 2). We recorded 32 food items, where Astyanax aff. fasciatus, Astyanax aff. paranae, and Astyanax bockmanni consumed a high proportion of plant remains, followed by terrestrial insects. Bryconamericus aff. iheringi consumed similar amounts of plant remains, seeds, Hymenoptera and immature Lepidoptera, while Bryconamericus stramineus consumed mainly Hymenoptera. The diets of Cetopsorhamdia iheringi, Characidium aff. zebra and Trichomycterus sp. were based on aquatic insects, especially immature Trichoptera, Ephemeroptera, Plecoptera and Diptera. The species with high intake of detritus were Hypostomus ancistroides, Hisonotus sp., Poecilia reticulata, and Rineloricaria aff. pentamaculata. Imparfinis schubarti primarily consumed aquatic insect remains and Amphipoda. Rhamdia quelen showed a distinctive diet, consuming Diplopoda, terrestrial insect remains, and Orthoptera (Table 3).

In order to interpret the diet data through the DCA, axes 1 and 2 were retained (eigenvalues 0.77 and 0.47 , respectively) (Fig. $2 \mathrm{a}-\mathrm{b}$ ). Axis 1 explained most of the data variability, where the species that consumed predominantly plant remains and terrestrial insects had lower scores, and the species that consumed detritus, algae and other benthic organisms had higher scores. The species that fed on aquatic insects, especially immature Ephemeroptera, Plecoptera, and Trichoptera, showed intermediate scores.

The differences found in the dietary composition among species were corroborated by the MRPP analysis $(\mathrm{T}=-19.3$; $\mathrm{A}=0.06 ; p<0.05)$, which also indicated significant differences in relation to sampling sites $(\mathrm{T}=-24.4 ; \mathrm{A}=0.02$; $p<0.05)$. The food items that contributed to this differentiation were Gastropoda and seeds at site 1; Hymenoptera, aquatic insect remains and plant remains at site 2; and immature Lepidoptera and algae at site 3 . The same analysis indicated a significant difference between hydrological periods $(\mathrm{T}=-191.8 ; \mathrm{A}=0.12 ; p<0.05)$. In the rainy period, Testate amoebae, Hymenoptera, Gastropoda, detritus, and Cladocera were the items that accounted for these differences; while during the dry period, the indicator items were immature Diptera and Coleoptera, algae, seeds, and plant remains (Table 4).

Diet overlap. In general, the diet overlap among species was low $(<0.4)$ for about $78 \%$ of pairs of species. Medium and high overlap values were recorded for all sites in both hydrological periods, but with frequencies lower than $15 \%$ (Fig. 3), and these values were related to the congeneric species of Characidae and individuals of Loricariidae that showed extensive overlap in the foods consumed. The means of diet overlap, evaluated through the Kruskal-Wallis test, did not indicate significant differences among the three sampling sites $(\mathrm{H}=5.48 ; p=0.06)$, or between the hydrological periods at each site (Site 1: $\mathrm{H}=$ $2.52, p=0.11$; Site $2: \mathrm{H}=2.35, p=0.12$; Site $3: \mathrm{H}=0.10, p=0.74$ ). According to the null model of Pianka's index, the values of diet overlap within each site in both hydrological periods were significantly higher than expected by chance (null communities) $(p<0.05)$, suggesting that these values are not random, i.e., showing evidence of resource sharing.

Food resources. When the food items were grouped into broader categories and compared by sites and hydrological

Table 2. Number of stomachs analyzed, for each fish species from Itiz stream, Ivaí River basin, Paraná State, Brazil.

\begin{tabular}{|c|c|c|c|c|c|}
\hline \multirow{2}{*}{ Order/Family/Species } & \multirow{2}{*}{ Species Code } & \multirow{2}{*}{$\begin{array}{c}\text { Voucher } \\
\text { specimens }\end{array}$} & \multicolumn{2}{|c|}{$\mathrm{N}$ analyzed stomachs } & \multirow{2}{*}{$\begin{array}{l}\text { Largest and smallest } \\
\text { standard length }(\mathrm{cm})\end{array}$} \\
\hline & & & Rainy & Dry & \\
\hline \multicolumn{6}{|l|}{ CHARACIFORMES } \\
\hline \multicolumn{6}{|l|}{ Crenuchidae } \\
\hline Characidium aff. zebra Eigenmann, 1909 & Cze & NUP 11817 & 25 & 23 & $3.00-5.70$ \\
\hline \multicolumn{6}{|l|}{ Characidae } \\
\hline Astyanax aff. fasciatus (Cuvier, 1819) & Afa & NUP 11797 & 36 & 43 & $2.70-10.92$ \\
\hline Astyanax aff. paranae Eigenmann, 1914 & Apa & NUP 11794 & 107 & 69 & $2.10-11.59$ \\
\hline Astyanax bockmanni Vari \& Castro, 2007 & Abo & NUP 11793 & 11 & 41 & $3.52-8.29$ \\
\hline Bryconamericus aff. iheringi (Boulenger, 1887) & Bih & NUP 11791 & 28 & 35 & $3.30-5.80$ \\
\hline Bryconamericus stramineus Eigenmann, 1908 & Bst & NUP 11818 & 16 & & $4.90-6.40$ \\
\hline \multicolumn{6}{|l|}{ SILURIFORMES } \\
\hline \multicolumn{6}{|l|}{ Trichomycteridae } \\
\hline Trichomycterus sp. & Tri & NUP 11800/11811 & 112 & 74 & $2.20-7.76$ \\
\hline \multicolumn{6}{|l|}{ Loricariidae } \\
\hline Hisonotus sp. & His & NUP 11808 & 15 & 13 & $2.50-4.00$ \\
\hline Rineloricaria aff. pentamaculata Langeani \& de Araújo, 1994 & Rpe & NUP 11815 & 58 & 23 & $1.70-9.80$ \\
\hline Hypostomus ancistroides (Ihering, 1911) & Han & - & 44 & 22 & $1.40-7.80$ \\
\hline \multicolumn{6}{|l|}{ Heptapteridae } \\
\hline Cetopsorhamdia iheringi Schubart \& Gomes, 1959 & Cih & NUP 11816 & 6 & & $1.80-7.20$ \\
\hline Imparfinis schubarti (Gomes, 1956) & Ish & NUP 11799 & 4 & 4 & $2.30-6.20$ \\
\hline Rhamdia quelen (Quoy \& Gaimard, 1824) & Rqu & NUP 11805 & 14 & 10 & $7.00-17.20$ \\
\hline \multicolumn{6}{|l|}{ CYPRINODONTIFORMES } \\
\hline \multicolumn{6}{|l|}{ Poeciliidae } \\
\hline Poecilia reticulata Peters, 1859 & Pre & NUP 11807 & 169 & 100 & $1.20-3.63$ \\
\hline Total number & & & 11 & & \\
\hline
\end{tabular}


Table 3. Food items consumed by the fish fauna in Itiz stream, Ivaí River basin, Paraná State, Brazil. Values based on data for volume percentage of the food item. Asterisk indicates values less than $0.1 \%$. See Table 2 from names of fish species.

\begin{tabular}{|c|c|c|c|c|c|c|c|c|c|c|c|c|c|c|}
\hline Food items/ fish fauna & Afa & Apa & Abo & Bih & Bst & $\mathrm{Cze}$ & Cih & Han & His & Isc & Pre & Rpe & Rqu & Tri \\
\hline \multicolumn{15}{|l|}{ AUTOCHTHONOUS } \\
\hline Testate Amoebae & $*$ & * & * & 1.1 & & 0.2 & & * & & $*$ & 8.7 & 0.8 & * & * \\
\hline Gastropoda & & & & & & 0.5 & & & & & 1.3 & & 0.1 & \\
\hline Acarina & & & * & & & 0.3 & & & & & $*$ & & & $*$ \\
\hline Amphipoda & & $*$ & & 1.4 & 0.3 & 2.8 & & & & 36.3 & 0.1 & 0.2 & 2.9 & 10.3 \\
\hline Decapoda & & & & & & & & & & & & & 7.3 & \\
\hline Cladocera & & * & & & & & & & & & * & & & \\
\hline Conchostraca & & & & & & $*$ & & & & & 0.3 & 0.3 & & \\
\hline Copepoda & & & & & & & & & & & * & & & \\
\hline Ostracoda & & * & * & 0.1 & $*$ & 1.9 & & & & & 0.1 & 1.1 & * & $*$ \\
\hline Ephemeroptera & 0.5 & 0.4 & 0.2 & 2.7 & 1.1 & 31.7 & 54.3 & & & 3.1 & 2.4 & 6.7 & & 17.5 \\
\hline Odonata nymph & & 0.3 & & 2.1 & & & & & & & 0.1 & & & 2.2 \\
\hline Plecoptera & 0.2 & 0.4 & 0.1 & 1.1 & & 2 & & & & & 0.5 & & & 15.4 \\
\hline Immature Coleoptera & 1 & 2.2 & 2.6 & 2.3 & 0.6 & 3.2 & & & & & 0.2 & 0.1 & 0.4 & 0.9 \\
\hline Trichoptera & 1.4 & 3 & 0.3 & 6.1 & 0.6 & 35.3 & 0.7 & & & 12.6 & 3.7 & 17.9 & 0.1 & 26.4 \\
\hline Immature Diptera & 3.6 & 1.2 & 1.9 & 8 & 0.4 & 13.6 & 8.3 & * & & * & 10.4 & 10.7 & 0.8 & 8.6 \\
\hline Immature Lepidoptera & 2.7 & 2.8 & 6.7 & 10.6 & 0.2 & & & & & & 0.3 & & & 2.2 \\
\hline Aquatic insect remains & 0.1 & 0.8 & 0.2 & 8.5 & 0.1 & 0.1 & 27.7 & & & 45.7 & 0.5 & * & 0.7 & 3.3 \\
\hline Scales & $*$ & & & 0.1 & & & & & & & & & $*$ & \\
\hline Fish & & 0.8 & 2.8 & & & & & & & & & & 5.7 & \\
\hline Algae & & & & & & & & $*$ & 1.5 & & 1.4 & 0.3 & & $*$ \\
\hline \multicolumn{15}{|l|}{$\overline{\text { ALLOCHTHONOUS }}$} \\
\hline Oligochaeta & & & & 1.9 & & 2.3 & & & & & $*$ & & 0.3 & 3 \\
\hline Diplopoda & & & & & & & & & & & & & 34.6 & \\
\hline Araneae & 0.2 & 0.6 & 0.3 & 0.8 & 0.8 & & & & & & & & 2.3 & \\
\hline Hemiptera & & 0.3 & 0.1 & 0.5 & 0.1 & & & & & & & & 2.7 & 0.1 \\
\hline Hymenoptera & 6.6 & 13.3 & 14.4 & 9.5 & 94.5 & & & & & & & & 2.2 & 0.4 \\
\hline Coleoptera & 5.9 & 7 & 4.6 & 4.2 & 0.5 & 1.3 & & & & & 0.7 & & 5.8 & 0.4 \\
\hline Adult Diptera & 1.7 & 0.4 & 0.1 & 0.2 & & 0.6 & & & & & 0.9 & $*$ & & \\
\hline Orthoptera & & 0.5 & & 0.7 & & & & & & & & & 11.8 & \\
\hline Terrestrial insect remains & 24.1 & 4.6 & 7.8 & 6.8 & & & & & & & 0.1 & & 13.7 & 1.4 \\
\hline Seeds & 4.6 & 5.9 & 3.4 & 11.4 & 0.4 & & & & & & * & & 0.1 & 1.2 \\
\hline$\underline{\text { Plant remains }}$ & 46.5 & 55.2 & 54.5 & 13.6 & 0.4 & 0.7 & 0.7 & & & 2.3 & 0.6 & 0.8 & 6.5 & 2.2 \\
\hline \multicolumn{15}{|l|}{ UNDETERMINED } \\
\hline Detritus & 0.8 & 0.2 & * & 6.4 & & 3.6 & 8.2 & 99.9 & 98.5 & & 67.7 & 61.2 & 1.9 & 4.3 \\
\hline
\end{tabular}
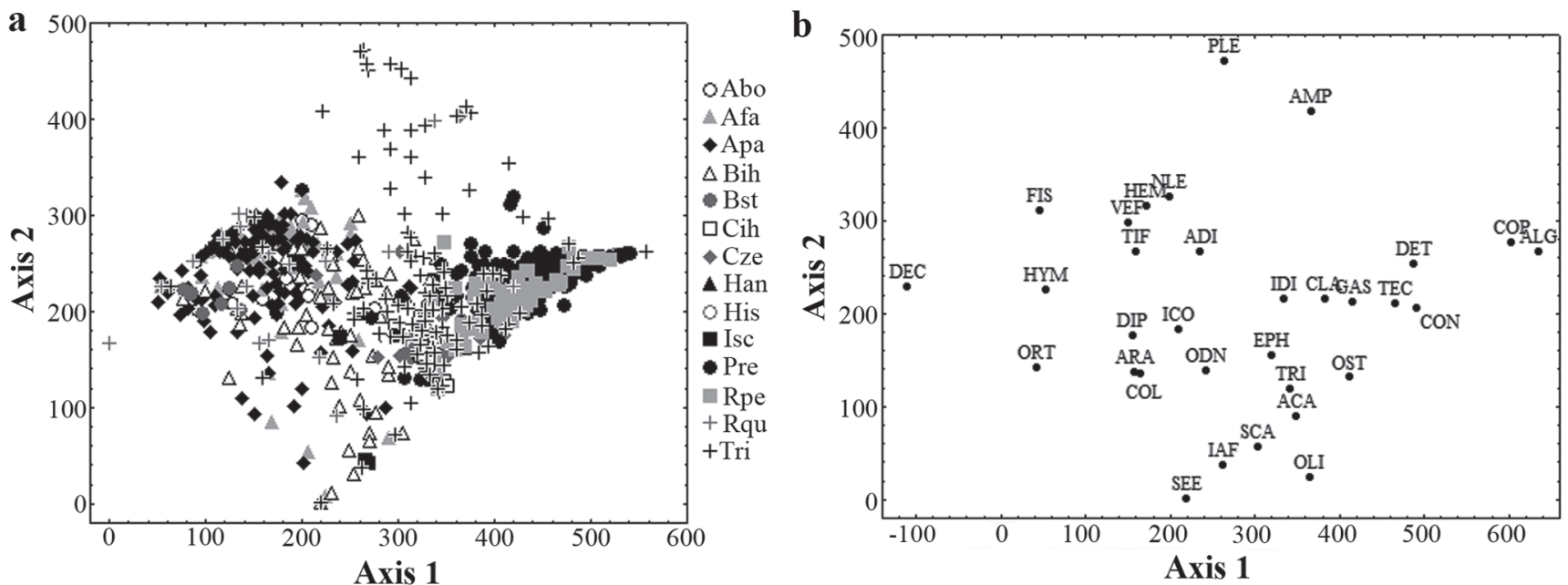

Fig. 2. Ordination of species (a) and food items (b) in Itiz stream, Ivaí River basin, Paraná State, Brazil, along the axis derived from Detrended Correspondence Analysis (DCA). See Table 2 for names of fish species. ACA = Acarina; ADI = Adult Diptera; ALG = Algae; $\mathrm{AMP}=\mathrm{Amphipoda} ; \mathrm{ARA}=$ Araneae $\mathrm{CLA}=$ Cladocera $\mathrm{COL}=$ Coleoptera; $\mathrm{CON}=$ Conchostraca; $\mathrm{COP}=\mathrm{Copepoda} ; \mathrm{DEC}=$ Decapoda; DET = Detritus; DIP = Diplopoda; EPH = Ephemeroptera; FAI = Aquatic insect remains; FIS = Fish; FTI = Terrestrial insect remains; $\mathrm{GAS}=$ Gastropoda; HEM = Hemiptera; HYM = Hymenoptera; ICO = Immature Coleoptera; IDI = Immature Diptera; ILE = Immature Lepidoptera; ODN = Odonata nymph; OLI = Oligochaeta; ORT = Orthoptera; OST = Ostracoda; PLA=Plant remains; $\mathrm{PLE}=$ Plecoptera; $\mathrm{SCA}=$ Scales; $\mathrm{SEE}=$ Seeds; TEA $=$ Testate amoebae; TRI $=$ Trichoptera . 
Table 4. Relative abundance (RA), relative frequency (RF) and Indicator value (Indval) of food items consumed by the fish community, discriminated among sites and hydrological period in Itiz stream, Ivaí River basin, Paraná State, Brazil. Only items with signicant values, $\mathrm{p}<0.05$, Monte Carlo permutation test are listed.

\begin{tabular}{|c|c|c|c|c|c|c|}
\hline Factor & Group & Food items & RA \% & $\mathrm{RF} \%$ & Indval & $p$ \\
\hline \multirow{7}{*}{ Sites } & Site 1 & Gastropoda & 95 & 4 & 4 & 0.000 \\
\hline & & Seeds & 73 & 7 & 5 & 0.012 \\
\hline & Site 2 & Aquatic insect remains & 51 & 17 & 8 & 0.043 \\
\hline & & Hymenoptera & 64 & 11 & 7 & 0.002 \\
\hline & & Plant remains & 49 & 37 & 18 & 0.005 \\
\hline & Site 3 & Immature Lepidoptera & 55 & 6 & 4 & 0.029 \\
\hline & & Algae & 51 & 19 & 10 & 0.008 \\
\hline \multirow{10}{*}{ Hydrological periods } & Rainy & Testate amoebae & 71 & 21 & 15 & 0.012 \\
\hline & & Hymenoptera & 73 & 17 & 12 & 0.000 \\
\hline & & Gastropoda & 94 & 3 & 3 & 0.005 \\
\hline & & Detritus & 57 & 51 & 29 & 0.034 \\
\hline & & Cladocera & 100 & 1 & 1 & 0.046 \\
\hline & Dry & Immature Diptera & 64 & 50 & 32 & 0.002 \\
\hline & & Immature Coleoptera & 59 & 12 & 7 & 0.046 \\
\hline & & Algae & 65 & 16 & 11 & 0.023 \\
\hline & & Seeds & 72 & 6 & 5 & 0.050 \\
\hline & & Plant remains & 64 & 43 & 27 & 0.000 \\
\hline
\end{tabular}

periods, at the three sampling sites, terrestrial invertebrates proved to be the resource that was most consumed by the fish fauna during the rainy period (values higher than $40 \%$ ). In the dry period, the main resource varied among the sites: at sites 1 and 2, terrestrial plants were the most consumed item ( $45.1 \%$ and $56.7 \%$, respectively), and at site 3, terrestrial invertebrates and terrestrial plants were most consumed (29.4\% and 25.8\%, respectively) (Figs. 4-5-6).

\section{Discussion}

The fish fauna used a range of food items, especially insects (terrestrial and aquatic), plants and detritus, corroborating the general dietary pattern described in the literature for tropical streams (Casatti, 2002; Borba et al., 2008; Brandão-Gonçalves et al., 2010; Mazzoni et al., 2010b; Tófoli et al., 2010; Schneider et al., 2011).

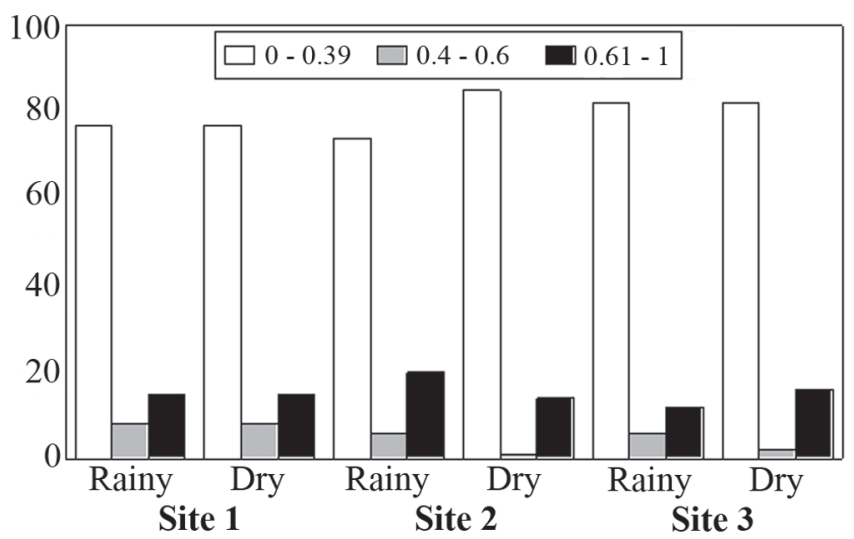

Fig. 3. Overlap values for the fish fauna of Itiz stream, Ivaí River basin, Paraná State, Brazil, using Pianka's index, for each sampling site in the rainy and dry hydrological periods. Diet overlap was considered low (0-0.39), intermediate (0.4$0.6)$ or high (0.61-1).
Patterns of food segregation were observed among the species in the present study, and this demarcation can be explained by differences in the use of microhabitats, trophic morphology, and feeding tactics. For example, in the case of microhabitat use, the characids Astyanax and Bryconamericus were positioned in the water column where they collect food items carried by the current and available on the water surface, such as terrestrial insects and plants; whereas the heptapterid Rhamdia quelen showed a benthic habit, foraging on the bottom. The generalist feeding habit in streams, especially for small characids, has been reported previously, since these species are usually trophic opportunists and may change their diet according to spatial variations and interactions with other species (Casatti et al., 2001; Bennemann et al., 2005; Abilhoa et al., 2008; Corrêa \& Silva, 2010; Uieda \& Pinto, 2011).

With regard to morphological adaptations for feeding and restricted to one type of food, a pattern was observed for the

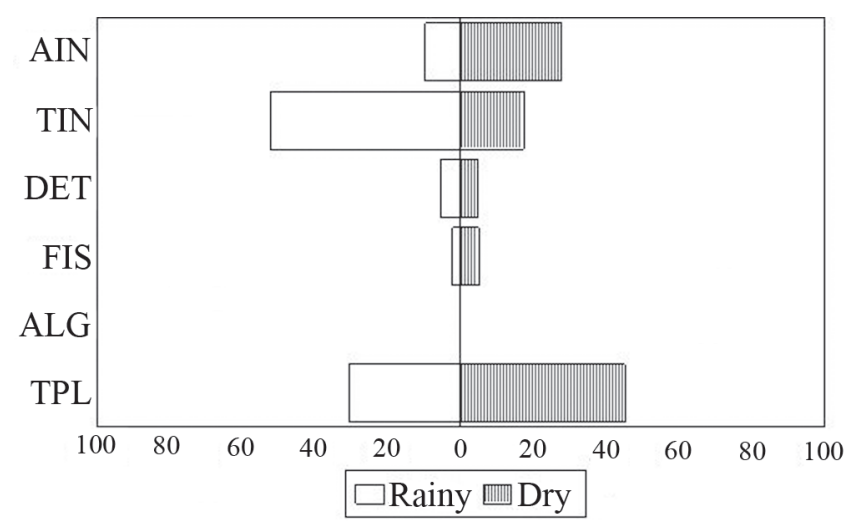

Fig. 4. Percentage composition of food resources consumed by fish species of Itiz stream, Ivaí River basin, Paraná State, Brazil, at site 1 in each hydrological period. AIN = aquatic invertebrates; $\mathrm{TIN}=$ terrestrial invertebrates; $\mathrm{DET}=$ detritus; $\mathrm{FIS}=$ fish $; \mathrm{ALG}=$ algae $; \mathrm{TPL}=$ terrestrial plants. 


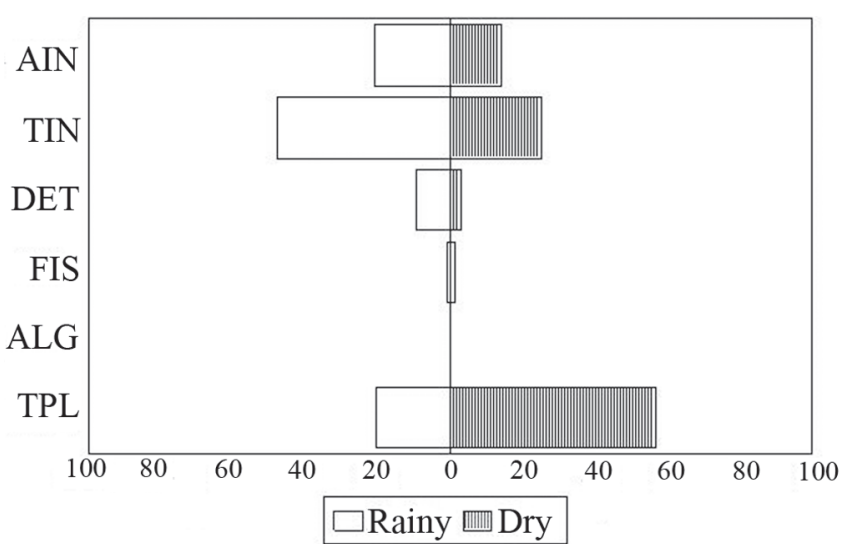

Fig. 5. Percentage composition of food resources consumed by fish species of Itiz stream, Ivaí River basin, Paraná State, Brazil, at site 2 in each hydrological period. AIN = aquatic invertebrates; $\mathrm{TIN}=$ terrestrial invertebrates; $\mathrm{DET}=$ detritus; $\mathrm{FIS}=$ fish; $\mathrm{ALG}=$ algae; $\mathrm{TPL}=$ terrestrial plants.

detritivorous species Hypostomus ancistroides, Hisonotus sp. and Rineloricaria aff. pentamaculata, as also observed in other tropical waters (Lowe-McConnell, 1999). These species have a feeding tactic of using predominantly benthic resources, where they collect algae, detritus, and other microorganisms (Oliveira \& Bennemann, 2005; Dias \& Fialho, 2011), aided by the ventral, sucker-shaped mouth (Delariva \& Agostinho, 2001; Casatti, 2005; Adriaens et al., 2009).

The segregation can also be guided by the availability of resources in the aquatic environment (Gerking, 1994; Casatti et al., 2009; Rezende et al., 2011), where a type of food is widely and continually available, this can favor nonrestrictive trophic specialization. This pattern was evident for Poecilia reticulata and for the insectivores Trichomycterus sp., Characidium aff. zebra and Cetopsorhamdia aff. iheringi, which capture benthic aquatic insects (Casatti, 2002; Abilhoa et al., 2008; Rezende et al., 2011). The high consumption of immature ephemeropterans, plecopterans and trichopterans was probably related to their high abundances in Itiz stream, as observed by Bagatini et al. (2012) in samples of macroinvertebrates collected simultaneously with this study.

The spatial variations observed in the dietary composition can be explained by the different microhabitats and characteristics of the surroundings of the sampling sites, which influence the supply of food resources. At site 1, water is pumped out for a cultivated area on the right bank, where papaya (Carica papaya L.) and other crops are grown. Different seeds from these plantations were abundant in the diets of several species, comprising a distinctive trophic feature for this site. At site 2, Bryconamericus stramineus was present in higher abundance and consumed predominantly hymenopterans. This site had the highest proportion of riparian vegetation, essential for the input of allochthonous items such as terrestrial insects and plants,

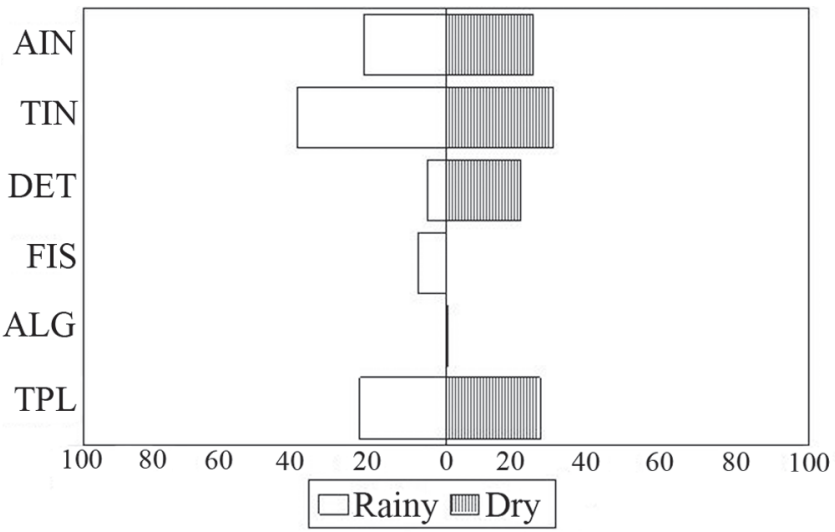

Fig. 6. Percentage composition of food resources consumed by fish species of Itiz stream, Ivaí River basin, Paraná State, Brazil, at site 3 in each hydrological period. AIN = aquatic invertebrates; $\mathrm{TIN}=$ terrestrial invertebrates; $\mathrm{DET}=$ detritus; $\mathrm{FIS}=$ fish $; \mathrm{ALG}=$ algae; $\mathrm{TPL}=$ terrestrial plants.

which were more important in this stretch of the stream. At site 3 , the indicator food items were related to the lessstructured riparian vegetation, which allows more light into the aquatic environment and thus increases autochthonous primary production (algae).

The hydrological periods also markedly influenced the availability of food in this stream. During the rainy period, the most important items were hymenopterans carried in by the rainfall, along with sediment from the surrounding areas, which caused an increase of items from the bottom, such as detritus, testate amoebae, gastropods and cladocerans. In the dry period, the situation was different, since the leaves and seeds fall into the water and serve as food for fish, and as a refuge for aquatic insects that are consumed together with this material.

The low overlap values observed suggest resource partitioning between most pairs of species. According to Schoener (1974), resource partitioning involves any substantial difference in the use of food that mitigates the effects of niche overlap and allows the species to coexist. Ross (1986) stated that in fish, segregation through food is considered among the most important factors. For the species examined in this study, the small overlap was related to the spatial and temporal differentiation observed in the dietary composition, the supply of food resources, and the different foraging tactics and dietary preferences by the species.

Resource partitioning among fish species from Neotropical streams is well reported in the literature, where the wide variety of aquatic and terrestrial organisms available as potential prey items leads to a wide diversity of tactics and feeding habits (Casatti, 2002; Barreto \& Aranha, 2006; Abilhoa et al., 2008; Brandão-Gonçalves et al., 2010; Alves et al., 2011; Cetra et al., 2011; Uieda \& Pinto, 2011).

High overlap values were recorded only between congeneric species of Characidae and Loricariidae, which 
because of their kinship, similar morphology and cooccurrence, used the same food sources (Casatti, 2002; Mazzoni et al., 2010c; Alves et al., 2011; Dias \& Fialho, 2011). However, this high overlap was probably associated with the high abundance of these resources (Bennemann et al., 2005; Dias \& Fialho, 2009; Uieda \& Pinto, 2011).

The mean dietary overlap did not vary for each sampling site or between hydrological periods at each site, revealing that the species did not significantly change their feeding habits; and the overlap occurred for the same pairs of species. Perusal of the literature reveals no discernible temporal pattern influencing the degree of diet overlap in rivers and streams. Studies suggest that during the dry season, the degree of overlap is higher, due to the scarcity of resources in this period (Deus \& Petrere-Junior, 2003). Nevertheless, Zaret \& Rand (1971), Tófoli et al. (2010) and Alves et al. (2011) recorded high values of overlap during the rainy season. In contrast, other studies have found no difference in the degree of overlap between the hydrological periods (Bastos, 2002; Dias \& Fialho, 2009, 2011; Johnson $\&$ Arunachalam, 2012), similarly to our results.

Grouping the food items into broader categories revealed differences in resource intake among the seasons of the year, which may be explained by the effect of seasonality on the life cycles of the organisms used as food (Wootton, 1990). During the rainy period, which in this region coincides with the warmest period of the year, the higher consumption of terrestrial invertebrates was due to greater emergence of arthropods, mainly adult insects, which, along with the rainfall, favors the transport of these organisms into the aquatic environment (Angermeier \& Karr, 1983; Rezende \& Mazzoni, 2005; Tófoli et al., 2010). In the dry season, the high intake of allochthonous plant material is caused by the lower current flow and water volume, which allows leaves and tree trunks to accumulate along the stream banks, making them available for the community (Schneider et al., 2011). The greater senescence of leaves of the Seasonal Semideciduous Forest, typical of the region, also contributed to this availability.

Plant material from riparian vegetation forms the base of the trophic chain of many aquatic ecosystems (Melo et al., 2004). According to Casatti (2010), changes in the composition and structure of riparian vegetation may cause alterations in food availability and consequently in the feeding habits of fish. This pattern was observed in this study, since this stream featured headwater characteristics, with low primary productivity, making the organisms dependent on allochthonous food resources.

Thus, the characteristics of the surroundings, degree of integrity of the riparian vegetation, and physiography of the channel at each site increased the availability of food items in the stream. These characteristics contributed to the higher consumption of allochthonous resources by the fish community, and, together with the different feeding tactics, were essential for the segregation and low trophic overlap in the species' diets.

\section{Acknowledgements}

We thank CESUMAR for providing logistical support for sampling and analyzing materials. Funding was provided by CNPq (Conselho Nacional de Desenvolvimento Científico e Tecnológico - process number: $111537 / 2008-8$ ) to K. O. B., and by PROBICCESUMAR to J. C. S. We also thank all our colleagues for helping in field work, Alessandro G. Bifi and Cláudio H. Zawadzki for helping to identify the species, and Jaime L. Pereira for preparing the map.

\section{Literature Cite}

Abelha, M. C. F., A. A. Agostinho \& E. Goulart. 2001. Plasticidade trófica em peixes de água doce. Acta Scientiarum, 23: 425-434.

Abilhoa, V., L. F. Duboc \& D. P. A. Filho. 2008. A comunidade de peixes de um riacho de Floresta com Araucária, Alto rio Iguaçu, sul do Brasil. Revista Brasileira de Zoologia, 25: 238-246.

Achard, F., H. D. Eva, H. Stibig, P. Mayaux, J. Gallego, T. Richards \& J. Malingreau. 2002. Determination of deforestation rates of the world's humid tropical forests. Science, 297: 999-1002.

Adriaens, D., T. Geerinckx, J. Vlassenbroeck, L. V. Hoorebeke \& A. Herrel. 2009. Extensive jaw mobility in suckermouth armored catshes (Loricariidae): a morphological and kinematic analysis of substrate scraping mode of feeding. Physiological and Biochemical Zoology, 82: 51-62.

Alves, G. H. Z., R. M. Tófoli, G. C. Novakowski \& N. S. Hahn. 2011. Food partitioning between sympatric species of Serrapinnus (Osteichthyes, Cheirodontinae) in a tropical stream. Acta Scientiarum. Biological Sciences, 33: 153-159.

Alvim, M. C. C. \& A. C. Peret. 2004. Food resources sustaining the fish fauna in a section of the upper São Francisco River in Três Marias, MG, Brazil. Brazilian Journal of Biology, 64: 195-202.

Angermeier, P. L. \& J. R. Karr. 1983. Fish communities along environmental gradients in a system of tropical streams. Environmental Biology of Fishes, 9: 117-135.

Araújo, M. I., R. L. Delariva, K. O. Bonato \& J. C. Silva. 2011. Fishes in first order stream in Ivaí River drainage basin, upper Paraná River Basin, Paraná state, Brazil. Check List, 7: 774-777.

Bagatini, Y. M., R. L. Delariva \& J. Higuti. 2012. Benthic macroinvertebrates community structure in a stream of the Northwest region of Paraná State, Brazil. Biota Neotropica, 12: 1. http://www.biotaneotropica.org.br/v12n1/pt/ abstract?article+bn00912012012 ISSN 1676-0603.

Balassa, G. C., R. Fugi, N. S. Hahn \& A. B. Galina. 2004. Dieta de espécies do Anostomidae (Teleostei, Characiformes) na área de influência do reservatório de Manso, Mato Grosso, Brasil. Iheringia, Série Zoologia, 94: 77-82.

Barreto, A. P. \& J. M. R. Aranha. 2006. Alimentação de quatro espécies de Characiformes de um riacho da Floresta Atlântica, Guaraqueçaba, Paraná, Brasil. Revista Brasileira de Zoologia, 23: 779-788.

Bastos, J. R. H. 2002. Biologia alimentar da taxocenose de peixes do rio Silveira (cabeceira do rio Pelotas), São José dos Ausentes, Rio Grande do Sul, Brasil. Unpublished MSc. Dissertation, Universidade Federal do Rio Grande do Sul, 67p.

Bennemann, S. T., A. M. Gealh, M. L. Orsi \& L. M. Souza. 2005. Ocorrência e ecologia trófica de quatro espécies de Astyanax (Characidae) em diferentes rios da bacia do rio Tibagi, Paraná, Brasil. Iheringia, Série Zoologia, 95: 247-254. 
Bicudo, C. E. M. \& R. M. T. Bicudo. 1970. Algas de águas continentais brasileiras chave ilustrada para identificação de gêneros. São Paulo, Fundação Brasileira para o Desenvolvimento do Ensino de Ciências, 227p.

Borba, C. S., R. Fugi, A. A. Agostinho \& G. C. Novakowski. 2008. Dieta de Astyanax asuncionensis (Characiformes, Characidae), em riachos da bacia do rio Cuiabá, Estado do Mato Grosso. Acta Scientiarum. Biological Sciences, 30: 39-45.

Brandão-Gonçalves, L., S. A. Oliveira \& S. E. Lima-Junior. 2010. Hábitos alimentares da ictiofauna do córrego Franco, Mato Grosso do Sul, Brasil. Biota Neotropica, 10: 21-30.

Brazil-Sousa, C., R. M. Marques \& M. P. Albrecht. 2009. Segregação alimentar entre duas espécies de Heptapteridae no Rio Macaé, RJ. Biota Neotropica, 9: 31-37.

Casatti, L. 2002. Alimentação dos peixes em um riacho do Parque Estadual Morro do Diabo, Bacia do Alto Rio Paraná, sudeste do Brasil. Biota Neotropica, 2: 1-14.

Casatti, L. 2005. Fish assemblage structure in a first order stream, southeastern Brazil: longitudinal distribution, seasonality, and microhabitat diversity. Biota Neotropica, 5: 75-83.

Casatti, L. 2010. Alterações no Código Florestal Brasileiro: impactos potenciais sobre a ictiofauna. Biota Neotropica, 10: 31-34.

Casatti, L., C. P. Ferreira \& F. Langeani. 2009. A fish-based biotic integrity index for assessment of lowland streams in southeastern Brazil. Hydrobiologia, 623: 173-189.

Casatti, L., F. Langeani \& R. M. C. Castro. 2001. Peixes de riacho do Parque Estadual Morro do Diabo, Bacia do Alto rio Paraná, SP. Biota Neotropica, 1: 1-15.

Cetra, M., G. R. Rondineli \& U. P. Souza. 2011. Compartilhamento de recursos por duas espécies de peixes nectobentônicas de riachos na bacia do rio Cachoeira (BA). Biota Neotropica, 11: 1-9.

Corrêa, F. \& G. C. S. Silva. 2010. Hábito alimentar de Astyanax asuncionensis (Géry, 1972) durante um período de seca e cheia, no Córrego do Onça, Coxim, Mato Grosso do Sul. Revista Brasileira de Biociências, 8: 368-372.

Delariva, R. L. \& A. A. Agostinho. 2001. Relationship between morphology and diets of six neotropical loricariids. Journal of Fish Biology, 58: 832- 847.

Deus, C. P. \& M. Petrere-Junior. 2003. Seasonal diet shifts of seven fish species in an Atlantic Rainforest stream in southeastern Brazil. Brazilian Journal of Biology, 63: 579-588.

Dias, T. S. \& C. B. Fialho. 2009. Biologia alimentar de quatro espécies simpátricas de Cheirodontinae (Characiformes, Characidae) do rio Ceará Mirim, Rio Grande do Norte. Iheringia, Série Zoologia, 99: 242-248.

Dias, T. S. \& C. B. Fialho. 2011. Comparative dietary analysis of Eurycheilichthys pantherinus and Pareiorhaphis hystrix: two Loricariidae species (Ostariophysi, Siluriformes) from Campos Sulinos biome, southern Brazil. Iheringia, Série Zoologia, 101: 49-55.

Dufrêne, M. \& P. Legendre. 1997. Species assemblages and indicator species: the need for a flexible asymmetrical approach. Ecological Monographs, 67: 345-366.

Esteves, K. E. \& J. M. R. Aranha. 1999. Ecologia trófica de peixes de riachos. Pp. 157-182. In: E. P. Caramaschi, R. Mazzoni, C. R. S. F. Bizerril \& P. R. Peres-Neto (Eds.). Ecologia de Peixes de Riachos: Estado Atual e Perspectivas. Rio de Janeiro, PPGEUFRJ, Oecologia Brasiliensis, VI.

Esteves, K. E. \& P. M. Galetti. 1994. Feeding ecology of Moenkhausia intermedia (Pisces, Characidae) in a small oxbow lake of Mogi-Guaçu River, São Paulo, Brazil. Internationale
Vereinigung fuer Theoretische und Angewnadte Limnologie Verhandlungen, 25: 2198-2204.

Esteves, K. E., A. V. P. Lobo \& M. D. R. Faria. 2008. Trophic structure of a sh community along environmental gradients of a subtropical river (Paraitinga River, Upper Tietê River Basin, Brazil). Hydrobiologia, 598: 373-387.

Gerking, S. D. 1994. Feeding ecology of fishes. San Diego, Academic Press, 416p.

Gotelli, N. J. \& G. L. Entsminger. 2001. EcoSim: null models software for ecology. Version 7. Acquired Intelligence and KeseyBear. Jericho, Vermont, USA. Available from: http:// garyentsminger.com/ecosim.htmi (30/August/2011).

Graça, W. J. \& C. S. Pavanelli. 2007. Peixes da planície de inundação do alto rio Paraná e áreas adjacentes. Maringá, EDUEM, 241p.

Grossman, G. D. 1986. Food resources partitioning in a rocky intertidal fish assemblage. Journal of Zoology, 1: 317-355.

Hellawell, J. M. \& R. A. Abel. 1971. Rapid volumetric method for the analysis of the food of fishes. Journal of Fish Biology, 3: 29-37.

Higgins, C. L. 2009. Spatiotemporal variation in functional and taxonomic organization of stream-sh assemblages in central Texas. Aquatic Ecology, 43:1133-1141.

Higgins, C. L. \& R. E. Strauss. 2008. Modeling stream fish assemblages with niche apportionment models: patterns, processes, and scale dependence. Transactions of the American Fisheries Society, 137: 696-706.

Hill, M. O. \& H. G. Gauch. 1980. Detrended correspondence analysis, an improved ordination technique. Vegetatio, 42: 47-58.

Hyslop, E. J. 1980. Stomach contents analysis: a review of methods and their application. Journal of Fish Biology, 17: 411-429.

Ipardes, Instituto Paranaense de Desenvolvimento Econômico e Social. 2007. Available from: http://www.ipardes.gov.br/cadernos/Montapdf.php?Municipio=85200 (21/October/2009).

Johnson, J. A. \& M. Arunachalam. 2012. Feeding habit and food partitioning in a stream fish community of Western Ghats, India. Environmental Biology of Fishes, 93: 51-60.

Juliano, S. A. \& J. H. Lawton. 1990. The relationship between competition and morphology. II. Experiments on co-occurring dytiscid beetles. Journal of Animal Ecology, 59: 831-848.

Lambin, E. F., H. J. Geist \& E. Lepers. 2003. Dynamics of land-use and land-cover change in tropical regions. Annual Review of Environment and Resources, 28: 205-241.

Leli, I. T., J. C. Stevaux \& M. T. Nóbrega. 2010. Dinâmica espacial da hidrologia da bacia do rio Ivaí. Boletim Geográfico, 28: 41-47.

Lorion, C. M. \& B. P. Kennedy. 2009. Riparian forest buffers mitigate the effects of deforestation on sh assemblages in tropical headwater streams. Ecological Applications, 19: 468-479.

Lowe-McConnel, R. H. 1999. Estudos ecológicos de comunidade de peixes tropicais. São Paulo, EDUSP, 535p.

Maier, A., C. H. Zawadzki, W. J. da Graça \& A. G. Bifi. 2008. Fish, Barra Bonita River, Ivaí River drainage, upper Paraná River basin, Paraná State, Brazil. Check List, 4: 336-340.

Matthews, W. J. 1998. Patterns in freshwater fish ecology. New York, Chapman \& Hall, 756p.

Mazzoni, R., R. R. S. Araújo, G. C. T. dos Santos \& R. IglesiasRios. 2010a. Feeding ecology of Phalloceros anisophallos (Osteichthyes: Cyprinodontiformes) from Andorinha Stream, Ilha Grande, Brazil. Neotropical Ichthyology, 8: 179-182.

Mazzoni, R., M. Moraes, C. F. Rezende \& J. C. Miranda. 2010 b. Alimentação e padrões ecomorfológicos das espécies de peixes 
de riacho do alto rio Tocantins, Goiás, Brasil. Iheringia, Série Zoologia, 100: 162-168.

Mazzoni, R., C. F. Rezende \& R. L. Manna. 2010c. Feeding ecology of Hypostomus punctatus Valenciennes, 1840 (Osteichthyes, Loricariidae) in a costal stream from southeast Brazil. Brazilian Journal of Biology, 70: 569-574.

McCune, B. \& J. B. Grace. 2002. Analysis of Ecological Communities. Oregon, MJM, 300p.

McCune, B. \& M. J. Mefford. 1999. PC-ORD. Multivariate Analysis of Ecological Data. Version 5.0. MjM Software, Gleneden Beach, Oregon, USA.

Melo, C. E., F. A. Machado \& V. Pinto-Silva. 2004. Feeding habits of fish from a stream in the savanna of Central Brazil, Araguaia Basin. Neotropical Ichthyology, 2: 37-44.

Mugnai, R., J. L. Nessimian \& D. F. Baptista. 2010. Manual de identificação de macroinvertebrados aquáticos do Estado do Rio de Janeiro. Rio de Janeiro, Technical Boocks, 174p.

Novakowski, G. C., N. S. Hahn \& R. Fugi. 2008. Diet seasonality and food overlap of the fish assemblage in a pantanal pond. Neotropical Ichthyology, 6: 567-576.

Oliveira, D. C. \& S. T. Bennemann. 2005. Ictiofauna, recursos alimentares e relações com as interferências antrópicas em um riacho urbano no sul do Brasil. Biota Neotropica, 5: 96-107.

Parolin, M., C. Volkmer-Ribeiro \& J. A. Leandrini. 2010. Abordagem ambiental interdisciplinar em bacias hidrográficas no Estado do Paraná. Campo Mourão, Fecilcam, 158p.

Pianka, E. R. 1973. The structure of lizard communities. Annual Review of Ecology and Systematics, 4: 53-74.

Power, M. 1983. Grazing responses of tropical freshwater fishes to different scales of variation in their food. Environmental Biology of Fishes, 9: 103-115.

Pusey, B. J. \& A. H. Arthington. 2003. Importance of the riparian zone to the conservation and management of freshwater fish: a review. Marine and freshwater research, 54:1-16.

Reinthal, P. N. 1990. The feeding habits of a group of herbivorous rock-dwelling cichlid fishes (Cichlidae: Perciformes) from Lake Malawi, Africa. Environmental Biology of Fishes, 27: 215-233.

Rezende, C. F. \& R. Mazzoni. 2005. Seasonal variation in the input of allochthonous matter in an Atlantic Rain Forest stream, Ilha Grande-RJ. Acta Limnologica Brasiliensia, 17: 167-175.

Rezende, C. F., R. Mazzoni, E. P. Caramaschi, D. Rodrigues \& M. Moraes. 2011. Prey selection by two benthic fish species in a Mato Grosso stream, Rio de Janeiro, Brazil. Revista de Biologia Tropical, 59: 1697-1706.

Ross, S. T. 1986. Resource partitioning in fish assemblages: a review of field studies. Copeia, 1986: 352-388.

Schneider, M., P. P. U. Aquino, M. J. M. Silva \& C. P. Fonseca. 2011. Trophic structure of a fish community in Bananal stream subbasin in Brasília National Park, Cerrado biome (Brazilian Savanna), DF. Neotropical Ichthyology, 9: 579-592.

Schoener, T. W. 1974. Resource partitioning in ecological communities. Science, 185: 27-39.

Sheldon, A. L. \& G. K. Meffe. 1993 Multivariate analysis of feeding relationships of shes in blackwater streams. Environmental Biology of Fishes, 37: 161-171.

Statsoft, Inc. 2005. Statistica (data analysis software system). Version 7.1. www.statsoft.com

Strahler, A. N. 1957. Quantitative analysis of watershed geomorphology. Transactions American Geophysical Union, 38: 913-920.
Suderhsa, Superintendência de Desenvolvimento de Recursos Hídricos e Saneamento Ambiental. 2009. Available from: http:/ /www.suderhsa.pr.gov.br/. (10/October/2009).

Tófoli, R. M., N. S. Hahn, G. H. Z. Alves \& G. C. Novakowski. 2010. Uso do alimento por duas espécies simpátricas de Moenkhausia (Characiformes, characidae) em um riacho da Região Centro-Oeste do Brasil. Iheringia, Série Zoologia 100: 201-206.

Tokeshi, M. 1999. Species coexistence: ecological and evolutionary perspectives. Oxford, Blackwell Science, 454p.

Uieda, V. S. \& T. L. F. Pinto. 2011. Feeding selectivity of ichthyofauna in a tropical stream: space-time variations in trophic plasticity. Community Ecology, 12: 31-39.

Winemiller, K. O., A. A. Agostinho \& P. E. Caramaschi. 2008. Fish ecology in tropical streams. Pp. 336-346. In: Dudgeon, D. (Ed.). Tropical Stream Ecology. California, Academic Press, 370p.

Winemiller, K. O. \& E. R. Pianka. 1990. Organization in natural assemblages of desert lizards and tropical fishes. Ecological Monographs, 60: 27-55.

Winemiller, K. O. \& L. C. K. Winemiller. 2003. Food habits of tilapiine cichlids of the Upper Zambezi River and floodplains during the descending phase of the hydrological cycle. Journal of Fish Biology, 63: 120-128.

Wootton, R. J. 1990. Ecology of teleost fishes. London, Chapman and Hall, 404p.

Zaret, T. M. \& A. S. Rand. 1971. Competition in tropical stream fishes: support for the competitive exclusion principle. Ecology, 52: 336-342.

Submitted January 23, 2012

Accepted April 13, 2012

Published June 29, 2012 